\title{
SSinteza
}

Impact of Internet on Business Activities

Uticaj Interneta na poslovanje u Srbiji i svetu

\section{LJUDSKI RESURSI I RAZVOJ JAVNE UPRAVE}

\author{
Milan M. Rapajić \\ Pravni fakultet Univerziteta u Kragujevcu
}

\begin{abstract}
:
Za modernu državu Srbiju neophodan je ubrzan razvoj odnosno reforma javne uprave. Reforma predstavlja sistemsko-funkcionalno, kadrovsko-organizaciono unapređenje javne uprave uz primenu delatnosti Novog-javnog menadžmenta i E-uprave. Novi-javni menadžment (New Public Management) zajednički je naziv za niz reformi javnog sektora, koje se sprovode tokom poslednjih dvadesetak godina u mnogim zapadnim državama i državama u tranziciji. Pored toga u radu se obraća pažnja na pojam E-uprave. Efikasno upravljanje u organima javne uprave ima strateški značaj za osnaženje kadrovskog potencijala, modernizaciju države i ubrzani privredni razvoj. U radu se poseban akcenat stavlja na upravljanje ljudskim resursima u državnoj upravi Srbije uz kratak osvrt na pojedina zakonska rešenja.
\end{abstract}

\section{Key words:}

ljudski resursi,

javna uprava,

razvoj,

novi-javni menadžment.

\section{UVOD}

Aktuelna sadašnjica koju odlikuje razvoj visokih tehnologija, nadiranje komunikacija i informacija zahteva efikasan ljudski faktor u procesu upravljanja i razvoja organizacija. Ne može se zamisliti uspešan razvoj javne uprave bez efikasnog upravljanja, ili kako se to popularno kaže adekvatnog menadžmenta. Menadžment predstavlja proces planiranja, organizovanja vođenja i kontrole materijalno - finansijskih, informacionih i ljudskih resursa u organizacijama, a sa stanovišta ovog rada reč je o procesu, koji se ostvaruje u upravnim organizacijama radi ostvarivanja ciljeva projektovanih $\mathrm{u}$ javnom interesu i efektno donesenih i efikasno sprovedenih odluka. U literaturi ljudski resursi se definišu kao: „ukupnost ljudskih potencijala u organizaciji, koji čine znanja, sposobnosti, veštine, kreativnost, motivaciju i radnu energiju potrebnu za ostvarivanje organizacionih ciljeva. To je ukupna intelektualna, psihička, fizička i socijalna energija koja može da se razvije u ostvarivanju organizacionih ciljeva." [1] Među najstarijim definicijama menadžmenta izdvaja se ona koja akcenat stavlja na obavljanje poslova pomoću ljudi. Među najznačajnijim funkcijama menadžmenta jeste ta da je reč o upravljanju ljudskim resursima. Menadžment je korisno znanje koje čoveku omogućuje da prvi put okupi produktivne ljude različitih nivoa znanja i stručnosti sa zajedničkim ciljem rada u jednoj upravnoj organizaciji. Upravljanje je svakako složen postupak sazdan od predviđanja, planiranja, komandovanja, koordiniranja i procesa kontrole. Kada je reč o upravljanju, treba naglasiti da on predstavlja proces kroz koji odabrana grupa ljudi usmerava sve službenike i nameštenike prema zajedničkom cilju koji je prvo zakonom i statutom, ili nekim drugim pra- vilnikom upravne organizacije određen. Upravljanje služi organizovanju resursa, a da bi se poslovi u upravnoj organizaciji adekvatno, odnosno uspešno obavljali. Pre pojma upravljanje, upotrebljavao se naziv personalna ili kadrovska funkcija, a pojam upravljanje ljudskim resursima je zamenio ovaj termin u teoriji 80 -ih godina XX veka. Kada je reč o upravljanju ljudskim resursima, čovek je stavljen u sam centar dešavanja u upravnoj organizaciji, jer je reč svakako o jednom od najbitnijih resursa. Upravna organizacija i njeno rukovodstvo, trebali bi da ljudski kapital razvijaju i održavaju u cilju ostvarenja opštih i pojedinačnih ciljeva. Takav pristup kod upravljanja ljudskim resursima akcenat stavlja na funkciju vođenja kao jednu od bitnih upravljačkih funkcija. Upravljačka funkcija, ili drugačije nazvano menadžment funkcija je supstituisala dotadašnje statične i sa stanovišta savremenog života anemične, personalne funkcije u upravnoj organizaciji. Poslovi koji se odnose na zaposlene u upravnoj organizaciji, dobili su strategijski značaj kao sastavni deo upravljačke aktivnosti i odgovornosti. S druge strane, ljudi su postali resursi i to zavisno od mesta koje imaju u radnom procesu. $\mathrm{Hu}-$ man Resourse Management - HRM, odnosno upravljanje ljudskim resursima je značajna naučna disciplina. Ona je interdisciplinarna, humanistička i aplikativna nauka, koja tretira ljudski rad kao društveni proces. Upravljanje ljudskim resursima kao interdiciplinarna naučna oblast, povezana je sa drugim naukama, kao što su: teorija menadžmenta; ergometrija; psihologija; ekonomija - Kada je reč o ekonomiji u teoriji se ističe da razvoj ljudskih resursa predstavlja jedno od bitnih područja ekonomskih nauka. Upravo se oblast ljudskih resursa može definisati kao onaj most između osnovnih i primenjenih nauka, koje su doživele svoj procvat u drugoj polovini dvadesetog i na počet- 
ku dvadeset prvog veka. Potvrdu opravdanosti takvog pristupa daje pre svega činjenica da danas najbolje rezultate najviše na planu ekonomskog i tehnološkog napretka i na tome zasnovanog kvaliteta života postigle one zemlje koje su najviše ulagale u razvoj ljudskih resursa [2]; sociologija; pravne nauke; androgogija; antropologija i medicina rada. Tako na primer, da bi se adekvatno upravljalo ljudskim resursima od strane menadžmenta upravne organizacije u javnoj upravi, potrebno je poznavati mnoge pojmove iz psihologije kao što su ponašanje, motivacija, selekcija, zadovoljstvo ili teorije menadžmenta koji treba da da odgovore na pitanje koji su osnovi principi organizacije i upravljanja u pogledu strukture sistema i vođstva. Kako upravljanje ljudskim resursima sublimira znanja navedenih nauka, može se konstatovati da je reč o „novoj naučnoj oblasti, odnosno novoj teorijskonaučnoj i nastavnoj disciplini, koja izučava navedene mere i aktivnosti radi njihove potpunije spoznaje i njihovog unapređivanja i prilagođavanja savremenim uslovima privređivanja." [3] Upravljanje ljudskim resursima je proces kome je osobena dinamičnost, permanentni razvoj, vremenska orijentisanost na sadašnjost i budućnost. Upravljanje ljudskim resursima obuhvata skup aktivnosti usmerenih na postizanje organizacionih ciljeva i zadovoljavanje ljudskih potreba u upravnoj organizaciji javne uprave. Tako Pržulj navodi, da se ciljevi menadžmenta ljudskih resursa izvode iz organizacionih ciljeva i moraju biti kompaktibilni sa njima. Zbog specifičnosti čoveka i njegove prirode, može se govoriti o dualnosti ciljeva menadžmenta ljudskih resursa: poslovni, odnosno ekonomski i socijalni ciljevi. [4]

\section{AKTIVNOST UPRAVLJANJA LJUDSKIM RESURSIMA}

Upravljanje ljudskim resurusima može da se razloži na nekoliko deonica i to: 1 . Planiranje i regrutovanje ljudskih resursa, 2. Selekcija, socijalizacija i procena učinka ljudskih resursa, 3. Obuka i dalja edukacija, 4. Unapređenje, premeštanje, devastiranje i prestanak radnog odnosa. Kada je reč o planiranju i regrutovanju, to su procesi koji pretpostavljaju da se potrebe kod zaposlenih zadovoljavaju stalno i na adekvatan način, što se postiže analizom unutrašnjih faktora. Pod unutrašnjim faktorima podrazumevamo trenutne i očekivane potrebe za određenim kadrovskim supstratom, popunjavanje upražnjenih radnih mesta, ali i eventualna redukcija organizacionih jedinica unutar upravne organizacije javne uprave. Pod regrutovanjem u javnoj upravi, podrazumevamo obezbeđenje odgovarajućeg i dovoljnog broja kandidata za radna mesta u javnoj upravi.

\section{UPRAVLJANJE LJUDSKIM RESURSIMA U JAVNOJ UPRAVI SRBIJE I NJEN RAZVOJ}

Dugogodišnje robovanje šablonima iz vremena socijalističkog samoupravnog sistema i naglašene etatizacije $u$ svim sferama života, uticalo je da je državna uprava u Srbiji postala jedan okoštali organizam koji nije bio spreman da prati tranzicione promene $\mathrm{u}$ srpskom društvu, drugim rečima na staro stablo nije bilo moguće kalemiti nove sor- te. Bila je potrebna sveobuhvatna reforma državne uprave, a šire posmatrano javne uprave na principima Novog javnog menadžmenta i implementacije E-uprave. „Pod javnom upravom u smislu Strategije Reforme javne uprave podrazumevaju se državna (centralna) uprava; subjekti koji vrše poverene upravne poslove; drugi nivoi upravnog odlučivanja - autonomna pokrajina i lokalna samouprava; i javne službe na centralnom i lokalnom nivou javnog upravljanja.“ [5] „Novi javni menadžment (New Public Management) zajednički je naziv za niz reformi javnog sektora, koje se provode tokom poslednjih dvadesetak godina u većini država OECD-a, zemljama u razvoju i tranzicionim zemljama. Ove se zemlje međusobno razlikuju s obzirom na svoje ekonomske, društveno-političke, kulturne, ustavne i institucionalne osobine, pa tako i načinu na koji se vodi javna uprava. Čak su i unutar razvijenih zapadnih zemalja upravne razlike velike. Uprkos tome, čini se da modeli reforme ne pokazuju isti stepen različitosti što ga pokazuju upravni elementi koji se reformišu.“ [6] „U stvari novi javni menadžment u operativnom smislu podrazumeva nametanje (ekonomskih) vrednosti i tehnika privatnog sektora javnom, odnosno naglasak je uglavnom na jeftinoći i efikasnosti, pouzdanje u moć privatnog preduzetništva i slobodnog tržišta u reformi javnog upravljanja. Od početka 1980-tih godina prošlog veka uglavnom je oslonjen na ideologiju neoliberalizma i konzervativne političke snage u SAD i Velikoj Britaniji. U stvari utemeljuje se na političkom „napadu“ na socijalnu državu, znanju, učvršćenju socijalne strukture, odnosno reafirmaciji nejednakosti i neokolonijalizma na globalnom planu" [7] Kada je reč o elektronskoj upravi radi se o „novom načinu upravljanja, kojim državna uprava svoje poslovanje orijentiše ka potrebama građana i privrede, a sve to uz pomoć savremenih informacionih i komunikacionih tehnologija. E-uprava, najjednostavnije rečeno, znači dostupnost servisa i usluga državne uprave elektronskim putem.Uvođenjem e-uprave značajno se unapređuje pružanje informacija i usluga korisnicima, a uz to se, što je veoma važno, olakšava i podstiče učešće građana i pravnih lica u procesima donošenja odluka. $\mathrm{Na}$ ovaj način postiže se veća transparentnost, odgovornosti efikasnost rada uprave, a celokupno poslovanje se usmerava prema korisnicima. Primena rešenja e-uprave predstavlja moćan alat za skraćivanje vremena prikupljanja, obrade i prenosa informacija. Obezbeđuju se tačniji podaci, premošćuje se fizička udaljenost subjekata koji komuniciraju, ostvaruju se vremenske uštede u pogledu troškova, smanjuje birokratija i postiže bolja dostupnost i otvorenost rada državne uprave. Korisnici mogu da jednostavnim korišćenjem interneta pribave najrazličitije informacije u vezi sa radom organa državne uprave. " [8]

Za vreme vlade Vojislava Koštunice doneta je Odluka o obrazovanju Saveta za reformu državne uprave kao centralnog strateškog tela Vlade za tu oblast. [9] Današnje Ministarstvo pravde i državne uprave je predložilo Vladi novu strategiju, koja mora biti zasnovana na analizi postojećeg stanja i kompariranja sa inostranim iskustvima i načelima i standardima Evropskog upravnog prostora. Svaka ozbiljna reforma je dugotrajan i kompleksan proces, koji se bazira na logičkom unutrašnjem sistemu. Tako i 
reforma državne uprave - šire posmatrano reforma javne uprave, mora da se bazira na osnovnim strateškim principima kao što su decentralizacija, depolitizacija, profesionalizam i racionalnost u radu uz primenu modernih tehnika, prilikom donošenja odluka i ciljeva nove reforme javne uprave, da bi se moglo govoriti o razvoju javne uprave $u$ pozitivnom pravcu, moraju da se fundiraju na načelima vladavine prava, zatim odgovornosti, javnosti, efikasnosti, ekonomičnosti i okrenutosti uprave ka građaninu. Javna uprava mora da se posmatra kao javni servis, odnosno javna služba, kako se to kaže u francuskom pravu. Naime, javna uprava posmatrana kao javna služba, jedan je od ugaonih kamena koncepta socijalne države. Vlada Srbije treba parlamentu da podnese Nacrt novog Zakona o državnim službenicima. Taj novi zakonski akt, valjalo bi da prati savremene tendencije u razvoju službeničkog prava. Sadašnji Zakon o državnim službenicima, koji je stupio na snagu 01.07.2006. godine, predstavljao je na normativnom planu značajni pomak u depolitizaciji i profesionalizaciji javne uprave, ali je faktičko stanje daleko od istinske depolitizacije javne uprave. Nažalost, to je bio akt koji predstavlja više formalnu proklamaciju. On je jedna vrsta normativne želje da državna uprava bude depolitizovana, a pregršt je primera suprotnog postupanja u praksi od načela i bazičnih postavki za upravljanje ljudskim resursima koje je zakon konstituisao. Ako bi se izvršila normativna analiza, što je namera u ovom radu, mogli bi samo da dođemo do pozitivnih zaključaka u vezi upravljanja ljudskim resursima na adekvatan način, shodno odredbama Zakona o državnim službenicima. Držeći se normativnog metoda kao vladajućeg metoda u pravnim naukama, ukazaćemo na osnovne i bitne elemente upravljanja ljudskim resursima, odnosno kadrovima $\mathrm{u}$ organima državne uprave i nosiocima javnih ovlašćenja, jednom rečju o upravljanju ljudskim resursima $u$ javnoj upravi. S obzirom na rečeno, Zakonom o državnim službenicima fundiran je normativni okvir za efikasniji i stručniji rad zaposlenih u organima javne uprave, dakle državnih službenika i nameštenika; uspostavljena su načela depolitizacije i profesionalizacije u radu, odgovornosti za vršenje javnih poslova koji se moraju sprovoditi shodno zahtevima struke i nauke uz adekvatnu motivaciju. Sa stanovišta radnog prava, preciznije rečeno službeničkog prava, normiran je na celovit i sistemski način položaj prava i dužnosti državnih službenika i određeni set prava i dužnosti nameštenika u radnopravnom smislu. Na taj način došlo je do konstituisanja službeničkog sistema, koji je kompatibilan savremenim, uporednopravnim rešenjima i standardima Evropske unije u ovoj oblasti. Zakonom o državnim službenicima došlo je do uvođenja karijernog poluotvorenog službeničkog sistema, koji se bazira na stručnosti - tzv. merit system. Ovim službeničkim zakonom, da ga tako drugačije nazovemo, uređen je kadrovski sistem i definisan pojam državnog službenika. Što se tiče teorijskog određenja državnog ili javnog službenika A. Baltić smatra da pojam javnog službenika u najširem smislu reči obuhvata mnogobrojne, raznovrsne i komplikovane pravne službene odnose, da on sadrži nekoliko pojmova koji se suštinski razlikuju i drugim rečima da obuhvata nekoliko kategorija javnih službenika. S obzirom na vreme u kome je stvarao ali i pravnu aktuelnost današnjice pomenuti autor službenike deli na stalne ili profesionalne činovnike, počasne javne službenike, prinudne javne službenike i javne službenike sa privatnopravnim karakterom (po ugovoru). [10] R.Marković smatra da lica u organima državne uprave čine ljudski supstrat tih organa. To su svi pojedinci koji su angažovani u obavljanju poslova i zadataka u organima uprave, imaju različit položaj u njima, različita ovlašćenja i dužnosti, pa se u skladu sa tim merilima mogu podeliti u određene grupe. [11] Inače u Zakonu o državnim službenicima došlo je do razgraničenja dve vrste poslova i to na poslove koje vrše državni službenici: reč je o licima koji rade na poslovima državne uprave i srodnim poslovima u ostvarenju javnog interesa, a kada je reč o nameštenicima to su lica koja rade na pratećim, pomoćnotehničkim poslovima. Iz gore navedenog da se zaključiti, a o čemu i zakon govori da je Republika Srbija poslodavac državnih službenika i nameštenika. Time je stvorena veća socijalna sigurnost ove dve kategorije zaposlenih u odnosu na stabilnost radnog mesta, posebno ako se njihov položaj komparira sa položajem zaposlenih u privatnom sektoru. Kada je reč o radnim mestima državnih službenika, ona se dele na položaje i izvršilačka radna mesta. Položajna radna mesta su složenija po broju zadataka koji imaju da se obavljaju i odgovornosti koja predstavlja prateću posledicu takvih radnih mesta. Izvršilačka radna mesta su manjeg stepena složenosti ovlašćenja i odgovornosti u odnosu na položajna, što naravno ne znači da u užim organizacionim jedinicama ministarstava i drugih organa javne uprave ta mesta ne predstavljaju krucijalnu kariku za adekvatno funkcionisanje mehanizma javne uprave. Upravo to je uslovilo da se izvršilačka radna mesta po novom sistemu zvanja razvrstavaju zavisno od složenosti poslova i odgovornosti, potrebnih znanja, sposobnosti i uslova za rad. Tako radna mesta sa visokim obrazovanjem, a koja su izvršilačkog karaktera se dele na poslove mlađeg savetnika, savetnika, samostalnog savetnika i višeg savetnika. Ako se uzme u obzir činjenica da se samostalni savetnici, odnosno viši savetnici nalaze na čelu odseka ili odeljenja određenog ministarstva, koja su nekad ključna u uspešnom funkcionisanju cele oblasti društvenog života koje pokriva nadležno ministarstvo, onda naša konstatacija da je reč o karikama koje su apsolutno neophodne za uspešno funkcionisanje javne uprave, odnosno njenih delova postaje potpuno tačna i ostaje trajno obeležje značaja ljudskih resursa u javnoj upravi. Radna mesta poslovi i zadaci kako položajna, tako i izvršilačka, imaju podlogu u Zakonu o državnim službenicima kada se razvrstavaju. Ali staro pravilo dobre normativne tehnike jeste da se zakon mora razraditti, odnosno detaljizovati podzakonskim aktima. Takva situacija je i u službeničkom pravu. Službeničko pravo demokratske pravne države, počiva na principima uspešnog delovanja državnih službenika. Da bi se delatnost državnih službenika mogla nazvati uspešnom, odnosno poneti takav epitet, oni mora da rade uz permanentno prisustvo zakonitosti, nepristranosti i političke neutralnosti. Državni službenik je dužan da postupa prema pravilima struke i da snosi odgovornost za svoj rad. Državnom službeniku mora da bude dostupna informaci- 
ja o radu da bi kvalitet usluga koje pruža javna uprava bio na nivou kakav je u vodećim zemljama Evropske unije. $\mathrm{Na}$ ta radna mesta državni službenici dolaze putem nepirstrasnog konkursa i mora da budu birani najsposobniji uz poštovanje principa jednake dostupnosti radnih mesta, napredovanja i stručnog usavršavanja i jednakih mogućnosti, što je takoreći zaštitni znak savremenog i odgovornog civilnog društva.

\section{ZAKLJUČAK}

Državni službenik je prva brana u zaštiti javnog interesa, postupajući u upravnom postupku na rešavanju prava i obaveza pravnih subjekata on ne sme delovati u svom interesu, odnosno postupati u svojoj stvari, s toga zakon reguliše kao civilizacijsku tekovinu sprečavanje sukoba interesa pri vršenju poslova. Zakon o državnim službenicima normirao je postupak zasnivanja radnog odnosa, odnosno zapošljavanja na osnovu kvalifikacija i sposobnosti. Da bi državna uprava bila efikasan mehanizam zaštite prava i interesa fizičkih i pravnih lica, ponavljamo u njene redove moraju biti primani najbolji, nezavisno od političkog opredeljenja ili rođačke konekcije sa visokim funkcionerima partije ili države. Stoga zakon reguliše popunjavanje izvršilačkih radnih mesta prvo internim konkursom, a kada to nije moguće onda na scenu stupa realizacija javnog konkursa. Svaki posao, a posebno onaj koji nosi epitet javnog, mora da bude podložan proveri i nadzoru radi unapređenja procesa rada i eventualnih korekcija grešaka koje su neminovne u takvom procesu. $S$ toga je zakonski predviđeno ocenjivanje i napredovanje državnih službenika u cilju njihovog motivisanja i ostvarivanje uslova za napredovanje i stručno usavršavanje. Potrebno je otprilike, da decenija prođe od momenta kada je lice sa visokom stručnom spremom zasnovalo radni odnos u organima javne uprave, da bi kroz protek tog vremenskog perioda od tog lica postao uspešni profesionalni, nepristrasni i pre svega stručni državni službenik. Svaka odgovorna javna uprava, a takva bi trebala da bude i srpska, mora da izdvaja deo finansijskih sredstava i materijalnih kapaciteta za stručno usavršavanje i osposobljavanje državnih službenika, međutim ne po principu stihije, naprotiv na osnovu striktno isplaniranog programa dugoročnog usavršavanja i mogućnosti dodatnog obrazovanja u matičnoj oblasti državnog službenika i eventualnoj prekvalifikaciji zbog potreba posla u upravnoj organizaciji javne uprave, ali i profesionalnih afiniteta državnog službenika, koje je pokazao prilikom rada u određenoj upravnoj organizaciji. U državnoj upravi, proces upravljanja kadrovima, odnosno ljudskim resursima je simbiotički povezan sa razvojem javne uprave. Nema istinskog progresa javne uprave i njene uspešne reforme ako je zakazala centralna služba za upravljanje ljudskim resursima. S toga je na nivou Vlade Republike Srbije osnovana Služba za upravljanje kadrovima i Visoki službenički Savet. Ova služba i Savet treba da svojim personalnim kapacitetima budu u službi razvoja javne uprave na pozitivnim tekovinama vladavine prava i principima pravne države.

\section{LITERATURA}

[1] Ž. Pržulj, „ Menadžment ljudskih resursa“, Institut za razvoj malih i srednjih preduzeća, Beograd, 2002, str. 1-22

[2] N.Stefanović, V.Marinković, „Ljudski resursi između ekonomije, prava i politike, Srpska politička misao br.1/2013, Beograd, 2013. str.173

[3] Ž. Kulić, „Upravljanje ljudskim resursima“, Beograd, 2002, str. 9

[4] Ž. Pržulj, „Menadžment ljudskih resursa“, Institut za razvoj malih i srednjih preduzeća, Beograd, 2002, str. 12.

[5] Radna verzija predloga Strategije Reforme javne uprave $u$ Republici Srbiji, Ministarstvo privrede i državne uprave, april 2013, str. 4

[6] M. Bjelica, „Komparativna analiza efikasnosti javnog menadžmenta u jugoistočnoj Evropi sa posebnim osvrtom na Istočno Sarajevo“, magistarski rad, Sremska Kamenica, 2012 , str. 8

[7] D. Subotić, „Novi-javni menadžment u političkom sistemu Srbije“, Politička revija br.1/2010, Beograd 2010, str. 93

[8] Elektronska uprava (E-uprava), Beograd, novembar 2012, Ministarstvo privrede i državne uprave, str. 8 , „Službeni glasnik RS“br. 73/04

[9] A. Baltić, „Opšta teorija pojma javnog službenika, s naročitim osvrtom na jugoslovensko zakonodavstvo i krivični zakonik, doktorska disertacija“, Beograd, 1938. str. 15

[10] R.Marković, „Upravno pravo“, Beograd, 2002, str.162-163

\section{HUMAN RESOURCES AND DEVELOPMENT OF PUBLIC ADMINISTRATION}

\footnotetext{
Abstract:

For the modern Serbian state rapid development and reform of the public administration is required. The reform represent systematic-functional and personnel-organizational improvement of public administration with the application of New Public Management and e-Government. New Public Management is a common name for several reforms of public sector, carried out during the last twenty years in many western countries and countries in transition. In addition, in this work attention is paid to the concept of e-government. Effectively managed in the public administration has a strategic importance for the strengthening of the potential of human resources, modernization of the state and faster economic development. This work puts special emphasis on human resources in Serbian public administration with a brief overview on certain legal solutions.
}

\section{Key words:}

Human resources, Public administration, Development, New Public Management 